\title{
The Strategy for the Development of the Arctic Zone of the Russian Federation through The Concept of a Regional Indicators System
}

\author{
Aleksandr Vladimirovich Kozlov ${ }^{1,2}$ \\ Svetlana Semenovna Gutman ${ }^{3}$ \\ Irina Mikhailovna Zaychenko ${ }^{3}$ \\ Elena Vladimirovna Rytova ${ }^{3}$ \\ 1 Institute of Industrial Economics and Management, World and Regional Economy Department, Peter the Great St. Petersburg \\ Polytechnic University, 195251, Polytekhnicheskaya St., 29, St-Petersburg, Russia \\ 2 University of Economy in Bydgoszcz, 85229, ul. Garbary, 2, Bydgoszcz, Poland \\ ${ }^{3}$ Institute of Industrial Economics and Management, World and Regional Economy Department, Peter the Great St. Petersburg \\ Polytechnic University, 195251, Polytekhnicheskaya St., 29, St-Petersburg, Russia \\ Correspondence: Aleksandr Vladimirovich Kozlov, Institute of Industrial Economics and Management, World and Regional Economy \\ Department, Peter the Great St. Petersburg Polytechnic University, St-Petersburg, Russian Federation \\ E-mail: avk55-spb@yandex.ru
}

Doi:10.5901/mjss.2015.v6n5s4p379

\section{Abstract}

The article presents an approach to the strategic development of the Arctic zone of the Russian Federation based on a system of regional indicators as transformation of the Balanced Scorecard method. The regional indicators system approach allows elaborating the general concept of comprehensive regional development taking into consideration economic and non-economic factors. The main peculiarities of the Arctic zone of Russian Federation are described. The general strategic chart of development of the Arctic zone was worked out based on the regional indicators system concept. The key target indicators of the strategic development of the Arctic zone are presented for the following strategic chart components: regional finance; society and market; industry and entrepreneurship; education, development, and innovations. These charts are to be integrated with the national strategic chart and regional charts of lower levels. The authors use cascading as a process of working out and transformation of comprehensive regional indicators based on the goal-oriented approach for every level of regional governance.

Keywords: regional strategic development, the Artic zone of the Russian Federation, the balanced scorecard approach, goaloriented planning, comprehensive regional indicators; strategic chart; monitoring system

\section{Introduction}

The Arctic zone of Russia is a unique area that comprises eight territorial entities, each having its own peculiar features. Its boundaries, however, are not the same as those of the subjects of the Russian Federation (ConsultantPlus, 2014; Rosstat, 2013). According to the Decree of President of Russia dated 02. 05. 2014, the Arctic zone of Russia consists of the following territories:

- The Murmansk Region.

- The Nenets Autonomous District.

- The Chukotka Autonomous District.

- The Yamalo-Nenets Autonomous District.

- The Vorkuta Municipal City District (part of the Komi Republic).

- The Allaikhovskiy Ulus (District), the Anabarskiy National (Dolgano-Evenkiyskiy) Ulus (District), the Bulunskiy Ulus (District), the Nizhnekolymsky District, the Ust-Jansky Ulus (District) (parts of the Sakha Republic (Yakutia).

- The Norilsk Municipal City District, the Taimyrskiy Dolgano-Nenetskiy Municipal District, the Turukhansky District (parts of the Krasnoyarsk Territory).

- The Municipal District of the City of Arkhangelsk, the Mezenskiy Municipal District, the Primorsky Municipal 
District, the City of Severodvinsk (the Arkhangelsk Region).

- The Arctic Ocean lands and islands, stated in the Resolution of Presidium of the Central Executive Committee of the USSR dated April 15, 1926 "Declaration on the Arctic Ocean lands and islands as the USSR territories" and others documents adopted in the USSR.

All the municipal district territories are included as of 01. 04. 2014.

For this and other reasons, the Arctic territories face a number of regional as well as global challenges and problems (Naumov \& Nikulkina, 2012; Karyakin, 2014; Mikhailov, 2013; Kozlov et al., 2014). This is why there is a need to conduct substantive assessment of the current situation, establish an integrated management system, and work out a comprehensive development strategy for the Russian Arctic. However, so far, there has been no consistent and scientifically grounded approach to the management of the Arctic, no methodology to work out a comprehensive regional development strategy. Every region defines its priorities and shapes its development strategy by itself. Furthermore, approaches to zoning the Arctic areas are yet to be fully articulated (Vasilyev \& Selin, 2013).

Traditionally the Russian North is only considered as a territory rich in raw materials. These resources are supposed to be the main factor of regional development. However, it is necessary to take into account the unique peculiar features of the Arctic zone of Russia:

- There are not only raw materials, but also multiple bio-resources, which are renewable when they are reproduced appropriately.

- There is not only a great amount of ecological problems, but also unique natural high-clearness zones.

- There are unique experience and traditions of the indigenous Arctic ethnic groups. Their way of life is the national cultural and historic heritage of Russia that has to be preserved and used for regional development.

- It is necessary to create and maintain favorable social environment for North inhabitants in the extreme climatic conditions.

- It is necessary to support employment in this region for indigenous Arctic ethnic groups and members of families of employees of budget-funded and large companies.

- "The Strategy for the Development of the Arctic Zone of the Russian Federation and National Security Efforts for the period up to 2020" singles out the following peculiar features of the Arctic zone of Russia, which form the Arctic state policy:

- Extreme climatic conditions (including constant ice cover and drift ice in the Arctic Ocean).

- Low population density and focal economic development of the territory.

- Remoteness from main economic centers of the country, intensive resource usage, strong dependence of the population and economy on fuel, food, and other important goods delivery from other regions of Russia.

- The ecological system forms biological balance and the Earth climate, but has low stability and strongly depends on insignificant anthropogenic influence.

The Russian Federation Government Program "The Program of Socio-Economic Development of the Arctic Zone of the Russian Federation until 2020" was approved on April 21, 2014. It is a part of "The Strategy for the Development of the Arctic Zone of the Russian Federation and National Security Efforts for the Period up to 2020" which was developed to implement the "The Basic Principles of the Government Policy of the Russian Federation in the Arctic for the Period up to 2020 and Further Prospects" approved by the President of the Russian Federation on September 18, 2008. These documents are the main ones for the Arctic region today because they form the region development priorities in the long view.

The main indicators of the 2020 Strategy implementation were analyzed:

- The ration of income of $10 \%$ well-off and $10 \%$ poverty-stricken population in the Arctic zone of Russia.

- The ratio of air traffic availability in the Arctic zone.

- The ratio of natural growth of population in the Arctic zone.

- The share of population in the Arctic zone of Russia who have constant access to standard drinkable water supply.

- The population of rare and disappearing species of animals included in the Red Book of Russia and inhabiting the Arctic zone.

- The volume of prevented ecological damage as a result of the search and rescue activity.

- The production share of the high-technology and innovation sector of the Arctic zone economy in the Gross National Product of the Russian Federation.

- The gain in the share of the Arctic zone in the Gross National Product of the Russian Federation and national export structure. 
- The gain in the volume of regional science-based and innovative products (and services) in the overall sales in Russia and abroad.

- The gain in the labor productivity growth rate at the Arctic zone enterprises.

- The gain in the balance reserves of minerals due to geological exploration in the Arctic zone of Russia.

- The gain in life expectancy of the indigenous Arctic ethnic groups inhabiting the Northern, Siberian, and Far Eastern regions of Russia.

In addition, many government programs of the Russian Federation function in the Arctic zone, as it is a part of Russia. The Russian government's program "The Program of Socio-Economic Development of the Arctic Zone of the Russian Federation until 2020" is supplemented with others documents, which pay particular attention to the Arctic zone and suggest specific government policy instruments.

An analysis of the documents shows a number of problems, which can negatively affect implementation of "The Program of Socio-Economic Development of the Arctic Zone of the Russian Federation until 2020" and achievement of target indicators.

First, the Strategy contains multiple priorities from other purpose-oriented programs, strategies, and development concepts. The excessive number of priorities makes affects their significance. The strategy becomes a multipurpose rather than purpose-oriented program. Also, the Strategy was planned as a medium-term program. This program's funding is limited and can be started only in 2015, when necessary entries will be included in the budget. The limited funding and unlimited purpose can disperse resources and impede achieving actual results.

The second negative trend is the primary attention to large-scale raw materials projects in this program. Obviously, large energy businesses need less government support than population, small businesses, and social environment in the Arctic zone. The comprehensive socioeconomic development of the Russian Arctic is more important for Russian strategic interests than the camp-type, which is cheaper and easier for large raw materials energy projects.

Today, 14 government programs are ongoing, which aim the Arctic zone development. But up to now, the Arctic Zone has not been assigned legal definition; there is no special legislation for supporting the socioeconomic development of the Arctic. However, there are more than 100 different regulations in federal laws, which govern socioeconomic relations in the Extreme North Region (it includes also the Arctic zone of Russia) (Lukin, 2014).

It looks more efficient to include not only an abstract plan in the program, but also a list of specific works with particular measures and scope of investment. It will help pay maximum attention to social problems of the Arctic inhabitants and improve their welfare. Also, it is important to adopt the new law "On the Arctic Zone of the Russian Federation," which would solve the main problems:

- The Arctic zone would be defined as a part of the Extreme North of Russia.

- The structure and borders attributes of the Arctic zone of Russia would be established.

- The institutional, organizational, and legislative conditions would be created and maintained.

- Federal level documents on the comprehensive strategy for systematic step-by-step solution of socioeconomic problems in the Arctic Zone would be developed and implemented.

- A balance between the special legal mechanism of regional policy in the Arctic, Russian legislation norms, and international agreements provisions would be achieved.

- The main principles of international collaboration of Russia with other Arctic countries would be legislated, and environment security would be provided.

- A mechanism of communication and decision-making coordination for regional governments in the Arctic zone would be developed.

Thus, this research aims to establish a conceptual framework for the strategy of the Arctic zone development based on a system of regional indicators.

\section{Existing Literature}

All the literary sources on the development strategy for the Arctic zone of the Russian Federation (AZRF) can be divided into two groups. The first group comprises legal documents (Presidential Decree; Government Program), which relate to general policy and offer no specific information on how to implement the abovementioned strategy in principle, let alone in every region in particular.

The second group includes suggestions made by the authors of research papers and monographs. But then again, most suggestions concern either regional or industry development, or they deal with separate issues of how to solve certain socioeconomic problems or how to use individual development tools. Kharitonova and Vizhina (2014), 
Ponomareva and Okhlopkov (2013), for example, address development concerns of some regions of Yakutia. Papers by S. I. Shevchenko et al. (2008), O. P. Sushko (2014), G. P. Kulakovsky and K. I. Alekseeva (2013), Yu. F. Lukin (2012) tackle demographic and transport accessibility issues, respectively. I. V. Nikulkina (2013), M. A. Krasnov et al. (2012), , A. B. Nikolaeva and V. S. Selin (2009), and D. P. Kondral (2014) suggest employing different tools and mechanisms to resolve the development challenges posed by the Arctic: financial and institutional mechanisms, technology clusters, and special economic zones.

A more important aspect of the problem is the tools to be used for regional strategic development. Many documents concerning regional strategic development are elaborated; however, a limited number of attempts have been made to apply modern ideas of strategic management to regional development planning. Tasaki, T. et al. (2010), proposed the elements of sustainable development and applied it to valuation and planning of countries' development. The same subject of analysis, namely, the national level, was regarded by Jung (1997) with a focus on environmental aspects. Hassan, O. A. B. (2008) developed a method to evaluate the sustainable development of a region based on adapting the multi-attribute utility theory. M. Holden (2006) proposed a system of key regional indicators for urban strategic planning.

Authors of (Marcela et al., 2011) and (Zavialova et al., 2014) proposed to use the Balanced Scorecard approach for modelling sustainable regional development, the idea of which is very fruitful on our opinion. However, implementation of this idea needs development and adaptation to specific regions. The attempt to apply ideas of sustainable development to the Murmansk Region was done by (Revich et al., 2014), but focus was made on social and demographic factors of the region. Ozkan and Schott (2013) focused on the problem of integration of collective and individual assets for the human development in the Arctic.

As can be seen from the above, the relevance of the comprehensive approach, which makes it possible to investigate issues relating to the elaboration and implementation of the development strategy for the Arctic zone, is brought about by the current absence of any comprehensive approach that would be applicable to all the Russian Arctic territories and could recognize all the elements of their development as parts of a whole.

\section{Methodology}

This research used a methodological framework constituted by the Balanced Scorecard (BSC) concept, on which the system of regional indicators (SRI) rests. The system groups region's characteristics based on certain classification criteria.

The main method of development and implementation of SRI is the Cascading, which is a process of working out and transforming comprehensive regional indicators based on the goal-oriented approach for every level of regional governance: the Arctic zone-territory-municipality-enterprise. The Cascading approach allows to integrate the top level SRI (the Arctic zone) and the indicators of lower levels (municipalities and enterprises located in the Arctic zone). Some of the indicators will be the same for all levels, but generally, the system of indicators on every level has peculiarities depending on competences and problems, which are specific for the level. Thus, the Cascading is a tool of strategic goals decomposing on separate elements according to hierarchy of the governing system of the Arctic zone of the Russian Federation. That means also the following: decomposing guidelines indicators from the level of the entire Arctic zone down to municipalities and enterprises converts goals into tasks for local authorities. Moreover, the Cascading method allows to elaborating a transparent structure of strategy implementation for the Arctic zone based on the goal-oriented approach. It helps also to develop a motivation system for regional authorities based on objective indicators for measuring their performance.

Thus, the study engaged quantitative and qualitative methods such as listed below:

1) The Cascading method was applied to the SRI (the Arctic zone-territory-municipal unit-enterprise). The authors of (Gershun \& Gorskiy, 2008) defined three principal methods of cascading:

- By the similarity of functions, which is the most relevant to regions with similar socioeconomic characteristics;

- By the principles of a holding company;

- By the hybrid method, which is a mixture of two abovementioned methods.

- The following stages of the Cascading method implementation exist separately from the applied method:

- Elaboration of the Cascading structure;

- Choice of a method of Cascading for every region and territory;

- Implementation of the Cascading process for all levels of the Arctic zone governance; 
- Valuation of the results and adjustment, if necessary.

2) Benchmarking was used to identify the most efficient techniques and greatest achievements in global practices relevant to regional development.

3) The Case method was employed to describe a set of regional indicators in respect to a particular region.

4) The Analog method was used to validate the application of the Balanced Scorecard in order to describe the regions and territories of the Russian Arctic.

5) The Synthesis method was employed to summarize the results of the content analysis.

\section{Findings and Proposals}

All regions of the Russian Federation determine their own strategy for sustainable development and accumulate funds to implement it, which is the basis for adapting the BSC concept and tools to a region as a structural economic unit. Besides, implementation of this concept makes it possible to attain sustainable development of a region if the following conditions are met:

- The aims and objectives of a strategy are consistent with the resources required for its implementation;

- The program for sustainable development of the region correlates with its short-term plans;

- The strategies of municipal entities are integrated into the strategies of the region;

- The budgets of the region and its municipal entities are brought into balance.

As mentioned above, the SRI methodology is built on the Balanced Scorecard developed by Kaplan and Norton $(1996,2004)$ as a strategic management system, which, in turn, is associated with the purposive approach. Yet, when BSC is to be applied to a region as an object of management, there is no way to engage the method directly, as it is business-oriented and treats every company or organization as a business unit with its own objectives. The SRI model was created with account of the region's characteristic properties. As the SRI system is based on the purposive approach, the Management by Objectives (MBO) approach to the Arctic Zone of Russia can be developed based on the strategic plans specially mapped out for each territory.

At the regional level, the SRI method is intended to formalize the development strategy of the Russian Arctic, to inform every head of a municipal entity (territory, enterprise) about this strategy, and to implement it, to provide monitoring (which is an Management by Objectives stage) and feedback at every level (specifically, region, territory, municipal entity, enterprise).

The SRI approach facilitates tying the strategy for the Russian Arctic with a basket of interrelating factors tailormade for different interconnected levels (those of a territory, municipal entity, and enterprise). This system shall balance out the economic, social, financial, and other performance results of regions (territories, municipal entities, enterprises) as well as aid in coordinating and pursuing strategies at every level.

The SRI of the Russian Arctic is a mechanism that allows for converting the AZRF development strategy into a sequence of activities aimed at attaining the objectives set at every management level. It improves the system of management by bringing the objectives of the head of a municipal entity (territory, enterprise) in line with those of the region.

Consideration of different elements relating to the development and implementation of the proposed program is a salient feature of the SRI concept and its centerpiece. Setting strategic objectives, selecting indicators, and arranging strategic activities covering all the SRI elements make for a tool that renders the concept of sustainable development for all the Arctic territories feasible.

The SRI elements of a macro-level organizational unit (territory, region, AZRF) include the following:

- Region's finances.

- The society and the market.

- An enterprise and an industry.

- Education, development, and innovations.

1) Regional finance. The targets are to seek ways to boost the region's earnings; to increase its investment appeal; to rationalize budget spending; to optimize resource (asset) utilization; to provide the region with an efficient infrastructure.

2) Market and society. The targets are to raise the living standards of citizens; to contribute to their social security; to maintain environmental security; to enhance the population's level of educational attainment.

3) Industry and entrepreneurship. The targets are to ensure further support and development of the principal employers and mainstays of entire towns; to develop innovation capacity; to support and develop small 
and medium enterprises; to rationalize legislative and regulatory provisions.

4) Education, development, and innovations. The targets are to take measures to enhance human potential, including intellectual capacity, and information capacity.

All the SRI elements are interrelated; they are consistent with the path of development within the Arctic, in general, and within every structural unit of the Arctic zone, in particular.

In view of the above, the following general strategy map of the Russian Arctic can be proposed (Figure 1). The Arctic development program comprises two key elements:

- Building an efficient socioeconomic system;

- Developing a mineral and raw material base.

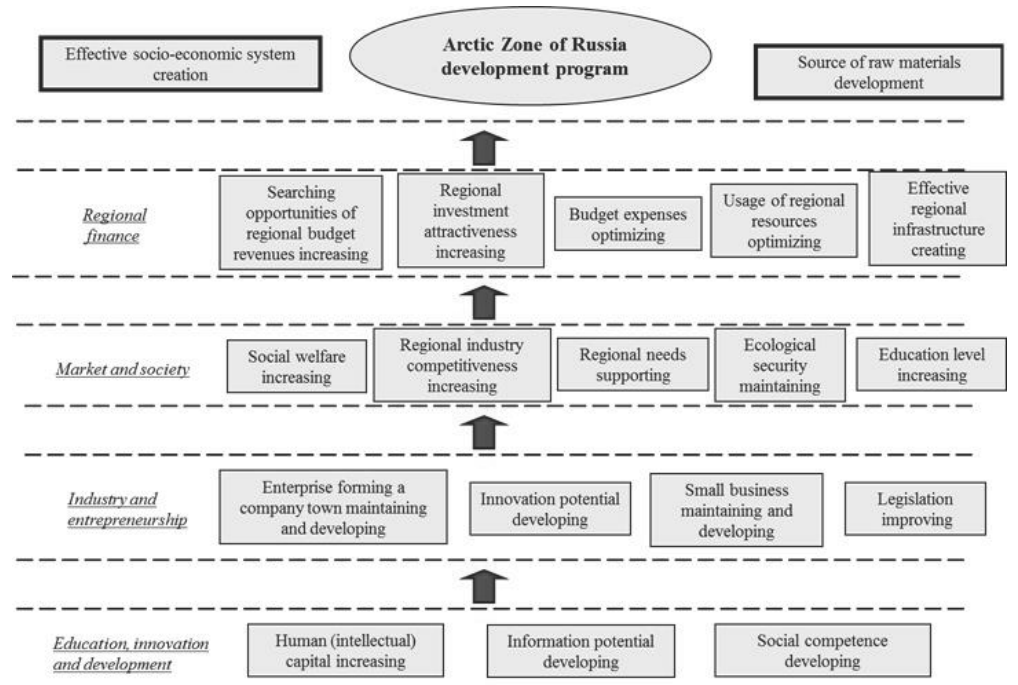

Figure 1. The map of the Artic zone of Russia strategy

Building an efficient socioeconomic system that involves, among others, the development of a mineral and raw material base requires taking measures relating to each SRI element. So, the region's incoming cash flow can be raised via the increase in income brought in by small-sized businesses. Those are to be developed in the areas inhabited by indigenous Arctic ethnic groups and are engaged in fishery, reindeer breeding, hunting, folk crafts, etc. Then, one cannot ignore the needs of backbone enterprises, such as, for example, OJSC ALROSA that employs $48 \%$ of Mirny's population (ALROSA Social Report, 2012). It is important to establish working institutional relationships that will facilitate integrating small-sized companies into the process flow and, in such a way, the value chain of big business. All of the above will provide for an efficient structure that will provide for better employment rates in the region, which will result in improvement of the living standards and educational attainment of the population. These outcomes will contribute to the accomplishment of the targets rendered in "Market and society." The enhanced infrastructure will be instrumental in keeping up the standards of environmental and social security in the region. To bring it all into effect, certain steps have to be completed, meaning that the current legislative and regulatory base is to be amended and the amendments are to be exercised under the supervision of government and public organizations. "Education, development, and innovations" is the last element of the general target system aimed at evolving the development program for the Arctic zone of Russia. The relevant activities should meet the following parameters: enhancement of human potential; development of information capacity and soft skills, expansion of innovation activities. In view of the fundamental SRI considerations, in order to develop the target of the research, particular tasks will be defined and task performance measures will be devised according to the bottom-up approach, starting with "Education, development, and innovations," continuing with "Industry and entrepreneurship", then with "Market and society", and finishing with "Regional finance" (Figure 2).

The goals to be achieved as a result of the Cascading are as follows:

- Development of SRI for every region of the Arctic zone;

- Identification of competitive advantages of every region; 
- Elaboration of strategic charts for every region and four elements;

- Development of a motivation system for all levels of regional governance;

- $\quad$ Keeping focus on strategic guidelines.

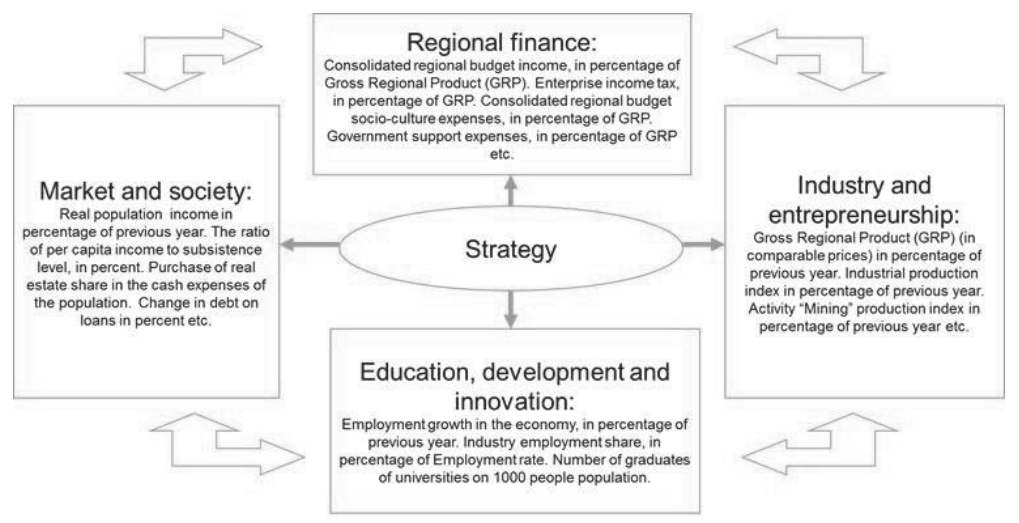

Figure 2. The system of regional indicators

\section{Discussions}

The discussable issues concerning the process of SRI development are as follows:

- How many indicators are to be included into SRI on all levels of hierarchy? An excessively massive system of indicators will not be easy to describe. A system including too many indicators will be confusing customers.

- Elaboration of regression equations is needed to quantify links between indicators and strategic guidelines of the Artic zone development.

- At developing SRI for the Arctic zone, the following peculiarity is to be taken into consideration: the Cascading of regional indicators is especially important for working out strategic charts for "Education, innovation, and development," since it is the most problematic area for understanding the general concept of the Arctic zone development.

\section{Conclusions}

Therefore, a system of indicators serves as a "command center," which allows setting specific targets and estimating relevant performance measures. Those are designed to facilitate the development of every territory within the Arctic zone and reflect its unique features. Also, applying SRI helps identify and efficiently utilize inherent Arctic resources (mineral raw material, intellectual, natural and climatic, production, trade, geopolitical, economic and immaterial), which are the prerequisites for successful implementation of the region development program. Strategy maps providing a representation of AZRF development act as general and consistent description of the development program and afford ground for adjusting objectives and corresponding indicators as well as managing the process of attaining these objectives.

The proposed SRI concept enables monitoring strategic initiatives being introduced. The main intended use of the system of indicators at the level of the region (AZRF) is to formalize the development strategy of the region, to inform every head of a municipal entity (territory) about this strategy and to implement it, to provide monitoring and feedback at every level (specifically, region, territory, municipal entity). In addition, by applying the Cascade Method, it is possible to bring the figures of the "High zone" in line with those of the "Low zone" (the Arctic regions) by establishing strategic aims and reference figures, which territories and municipal entities will draw on in order to monitor their contribution to the joint effort toward a common goal-the sustainable development of the Russian Arctic.

\section{Acknowledgements}

This paper is based on research carried out with the financial support of the grant of the Russian Science Foundation 
(project № 14-38-00009). Peter the Great St. Petersburg Polytechnic University.

\section{References}

Gershun, A., \& Gorskiy, M. (Eds.). (2008). Golden pages: The best examples of Balanced Scorecard implementation. Moscow: ZAO Olimp-Biznes.

The Russian Federation Government Program "The Program of Socio-Economic Development of the Arctic Zone of the Russian Federation until 2020" No. 366 dated April 21, 2014. Consultant.ru. Retrieved from http://base.consultant.ru/cons/cgi/online. cgi?req=doc;base $=$ LAW; $n=172466$

Haritonova, V. N., \& Vizhina, I. A. (2014). Economy of the Arctic zone of Eastern Yakutia innovative modernization: Problems and solutions. Region: Ekonomika i Sociologiya, 3(83), 31-57.

Hassan, O. A. B. (2008). Assessing the sustainability of a region in the light of composite indicators. Journal of Environmental Assessment Policy and Management, 10(1), 51-65.

Holden, M. (2006). Urban indicators and the integrative ideals of cities. Cities, 23(3), 170-183.

Jung, W. (1997). Sustainable development in industrial countries: Environmental indicators and targets as core elements of national action plans. The German Case. Sustainable Development, 5(3), 139-147.

Kaplan, R., \& Norton, D. (1996). The Balanced Scorecard: translating strategy into action. Harvard: Harvard Business Press.

Kaplan, R., \& Norton, D. (2004). Strategy maps: Converting intangible assets into tangible outcomes. Boston: HBS Press.

Karjakin, V. V. (2014). Arctic natural recourses-source of conflicts and challenge for regional stability. Trendy i Upravlenie, 3, 209-221.

Kondral, D. P. (2014). New issue about development process strategic management in Russian North. Arktika i Sever, 15, 186-189.

Kozlov, A. V., Gutman, S. S., \& Zajchenko, I. M. (2014). The development program of the Arctic zone based on the set of regional indicators. Bulletin of the Trans-Baikal State University, 11(114).

Krasnov, M. A., Sokolov, V. G., \& Shhenkova, T. A. (2012). Clustering of technological development of the regional economy. Scientific Notes of the Russian Academy of Entrepreneurship, 31, 57-65.

Kulakovskiy, G. P., \& Alekseeva, K. I. (2013). Problems and solutions of transport accessibility Northern regions by the example of the Arctic territories of the Republic of Sakha (Yakutia). Innovacii v Nauke, 24, 218-223.

Lukin, Y. F. (2012). The Russian Arctic in the changing world. Arhangelsk: SAFU. Retrieved from http://narfu.ru/aan/Russian_Arctic_ Lukin/Russian_Arctic_Lukin.pdf

Marcela, K., Michaela, \& Ondrej, S. (July 2011). Dynamic Balanced Scorecard: Model for sustainable regional Development. WSEAS Transactions on Environment and Development, 7(7), 211-221.

Mikhaylov, D. A. (2013). On some issues of comprehensive security of the Russian Arctic. Strategiya Grazhdanskoy Zashchity: Problemy i Issledovaniya, 3(1), 52-56.

Naumov, V. V. (2012). Factors influenced on the formation and development of the Arctic territory. Innovation of the Russian Economy and Globalization Processes: Proceedings of the Online-conference. Russian Plekhanov Economic University.

Nikolaeva, A. B., \& Selin, V. S. (2009). Problems and perspectives of special economic zones formation in the Russian Arctic. Apatity: Publisher Kola Science Centre of the Russian Academy of Science.

Nikulkina, I. V. (2013). Finance-institutional mechanism of sustainable development of the Arctic territories. Vestnik Ekonomicheskoy Integratsii, 9(66), 52-56.

Ozkan, U. R., \& Schott, S. (2013). Sustainable Development and Capabilities for the Polar Region. Social Indicators Research, 114(3), 1259-1283.

Ponomareva, G. A., \& Ohlopkov, M. N. (2013). Problems of spatial and socio-economic development of the Arctic zone ulus of the Republic of Sakha (Yakutia). Natsionalnye Interesy: Prioritety i Bezopasnost, 47, 20-25.

Regions of Russia. Cities' Main Socio-Ecoinomic Indicators. (2013). gks.ru. Retrieved from http://www.gks.ru/bgd/reg//b13_14p/Main.htm

Shevchenko, S. I., Popova, N. D., Titovskij, L. A., \& Dmitrieva, E. G. (2008). Demographic problems solution in the Yamal-Nenetskiy Autonomous District. Uroven Zhizni Naseleniya Regionov Rossii, 6, 3-36.

Socio-ecological report. (2012). alrosa.ru Retrieved from http://sr2012.alrosa.ru/rus/ekonomicheskaya-effektivnost/vklad-v-ekonomic heskoe-razvitie-regiona.html

Revich, B. A., Kharkova, T. L., Kvasha, E. A., Bogoyavlenskii, D. D., Korovkin, A. G., \& Korolev, I. B. (2014). Sociodemographic limitations of the sustainable development of Murmansk oblast. Studies on Russian economic development, 25(2), 201-206.

Sushko, O. P. (2014). Employment potential of the Russian Arctic. Arktika i Sever, 16, 72-83.

Tasaki, T., Kameyama, Y., Seiji, H., Moriguchi, Y., \& Hideo, H. (2010). A survey of national sustainable development indicators. International Journal of Sustainable Development, 13(4), 337-361.

Vasilyev, V. V., \& Selin, V. S. (2013). Methodology of complex nature-economic zoning northern territories and the Russian Arctic. Apatity: Publisher Kola Science Centre of the Russian Academy of Science.

Decree of the President of the Russian Federation "About the Land Territory of the Russian Arctic" dated 02. 05. 2014 Consultant.ru. Retrieved from http://base.consultant.ru/cons/cgi/online.cgi?req=doc;base=LAW;n=162553

Zavyalova, V., Norkina, A., \& Mindlin, Y. (2014). Visualization of working versions of Balanced Scorecard strategy maps in managing regional competitiveness. Life Science Journal, 11(11), 547-549. 